\title{
Challenges and opportunities for the creation of a multidisciplinary synergy in a university environment
}

\section{Retos y oportunidades para la creación de una sinergia multidisciplinaria en un entorno universitario}

\author{
HERNÁNDEZ-TINOCO, Araceli†* \& CARBAJAL-MARISCAL, Oscar \\ Centro Universitario de Ciencias Biológicas y Agropecuarias, CUCBA de la Universidad de Guadalajara. Camino Ramón \\ Padilla Sánchez 2100, Nextipac, 45200 Zapopan, Jal. México.
}

ID $1^{\text {st }}$ Author: Araceli, Hernández-Tinoco / ORC ID: 0000-0002-8420-0350-95748

ID $1^{\text {st }}$ Co-author: Oscar, Carbajal-Mariscal / ORC ID: 0000-0001-5373-3062-241918

DOI: $10.35429 / J U M .2021 .14 .5 .1 .7$

Received July 12, 2021; Accepted December 30, 2021

\begin{abstract}
It reflects on the establishment of a multidisciplinary collaboration approach between teachers and students of the Marketing and Food Science careers of two university centers of the University Network of Jalisco, Mexico, in order to create the image of the product, the communication and marketing strategy of the product and the legal framework of collaboration between them. In this way, with the aim of promoting entrepreneurship in the classroom, the students of the Marketing career operated on a new food product developed by their food science peers, to create a professional business plan, susceptible to registration with the intellectual property instance and with potential to market. The methodology for teaching collaboration is presented and the challenges for obtaining effective results are highlighted. All information is qualitative-anecdotal. Among the results, the role of the actors and the tangible and intangible requirements necessary for the optimal execution of a work of this type stand out.
\end{abstract}

Teaching collaboration, legal framework, Intellectual property, Synergy

\section{Resumen}

Se reflexiona sobre el establecimiento de un planteamiento de colaboración multidisciplinaria entre los docentes y los alumnos de las carreras de Mercadotecnia y Ciencia de los Alimentos de dos centros universitarios de la Red Universitaria de Jalisco, México, con la finalidad de crear la imagen del producto, la estrategia de comunicación y de comercialización del producto y el marco legal de colaboración entre ellos. De esta manera, con el objetivo de propiciar el emprendimiento en el aula, los estudiantes de la carrera de Mercadotecnia operaron sobre un nuevo producto alimenticio desarrollado por sus pares de Ciencia de los Alimentos, para crear un plan de negocio profesional, susceptible de registro ante la instancia de propiedad intelectual y con potencial para comercializar. Se expone la metodología para la colaboración docente y se destacan los retos para la obtención de resultados eficaces. Toda la información es cualitativo-anecdótica. Entre los resultados se destaca el rol de los actores y los requerimientos tangibles e intangibles necesarios para la ejecución óptima de un trabajo de este tipo.

Colaboración docente, Marco legal, Propiedad intelectual, Sinergia

Citation: HERNÁNDEZ-TINOCO, Araceli \& CARBAJAL-MARISCAL, Oscar. Challenges and opportunities for the creation of a multidisciplinary synergy in a university environment. Journal University Management. 2021. 5-14: 1-7

\footnotetext{
* Author Correspondence (e-mail: araceli.hernandez@academicos.udg.mx).

$\dagger$ Researcher contributing as first author.
} 


\section{Introduction}

Hybrid educational models, electronic government, electronic commerce (e-commerce) and the emergence of social networks in the various aspects of daily life, among many others, are part of the structural changes exacerbated by the COVID pandemic -19 . These trends were already taking shape at all levels of modern societies, but there had been no disruptive phenomenon that established them as guidelines in the lives of ordinary citizens.

During the recent experience of a global crisis derived from a health problem caused by COVID-19, the "comfort zones" were eliminated in the various spheres of human activities, including traditional teachinglearning methods, which changed in ways irreversible. Based on this series of experiences, it is considered essential to promote in society the preparation for any global emergency that involves health, the economy, armed conflicts and threats of various kinds.

Given the need to fully understand the teaching methodology in the competency-based educational model during the previous period and during confinement due to the public health contingency, reality has shown that the students were not working that way and their performance In "learning by doing" it had serious limitations, so the determination was made to intervene in the ways in which disciplinary subjects were being taught at the undergraduate level, according to the educational model already mentioned. The competencies were implemented to improve the profile of the students, who turned out to be deficient when they did not demonstrate efficient results and effective performance (Argüellez, 1996. Sileny and Gómez, 2008).

At the initiative of the author of this article and taking advantage of the diverse and varied training received over almost 30 years, in forms of teaching and learning, innovation and disruptive and exponential entrepreneurship in the most outstanding institutions in the world, it is proposed and implemented a linking strategy called "Synergy" in which students from the Food Science career (CALI), from the University Center for Biological and Agricultural Sciences.
Who during their career create, characterize and validate an innovative food product and with added value, they allow Marketing students (MERCA), from the University Center for Economic and Administrative Sciences, to develop, for such a food product, a very complete business plan that includes methodology and guidelines learned by the professors involved in international training.

In this way, students and teachers from two different careers relate, collaborate, share, and the beginning of a potential business synergy is promoted that passes to the incubation stage at the university at the end of the school year. This interactive linking model is the ideal one that is intended to be achieved through this inter-center and inter-career collaboration, but which until now, after four semesters, has presented serious obstacles due to various factors, which will be exposed and discussed in order to find and propose possible solutions.

\section{Theoretical framework}

\section{Competencies}

The educational model based on competencies has been outlined for several decades as the hegemonic model in educational institutions in our country. Echavarría and De los Reyes (2017) critically analyze the educational model based on competencies, mentioning that it is imperative to change educational parameters so as not to consider educational quality as the insertion of students in the productive sector but also to give value to the pedagogical aspects and the socio-cultural function of education that can hardly be measured with scales and evaluation results (Aguilar, 2021).

The authors insist on indicating that "the dominance of the business perspective in [education] is generating a lack of intellectual reflection and academic criticism oriented towards a better understanding of the various national contexts, while this pragmatic model leaves aside holistic visions and criticisms of our realities. "To the extent that this hegemonic model is replaced by other more inclusive and socially responsible visions, as well as respectful of traditions, we consider it important to recognize the valuable constructivist contribution of this educational model, particularly in the creative actions of students from different areas. 
Disciplines such as food science and marketing in the design of brand image of new food products and its analysis of market price that prospects and projects it beyond Mexican borders.

For their part, university teachers exercise a double profession. They are competent in the areas in which they prepared in their professional training careers and are also dedicated to being educators and trainers and are required to do so with the due pedagogical knowledge of excellence that university students require. This scientific pedagogical training takes place through the effort to improve in their own performance, through multiple and varied trainings and interventions in scientific and methodological activities as part of their work activity (Martín et al., 2017).

At a global level, a rethinking of skills can be identified (Taylor, 2021), targeting in the first place, distance training due to the phenomenon of the COVID-19 pandemic.

\section{Macro trends}

They are the global trends that direct, endure over time, affect the policies of world governments and companies and that can become imposed as lifestyles in society. These are dynamic and change every two to three years. Below are the main current global macro-trends, according to the World Trends Watch Report 2021, presented by IBTM World and Alistair Turner, which are used for planning, design, creation, among other activities.

\begin{tabular}{|l|}
\hline Macro trends \\
\hline The sustainability \\
\hline Safety \\
\hline Welfare \\
\hline The inclution \\
\hline Virtual experiences \\
\hline
\end{tabular}

Table 1 Macro trends

Source: World Trends Watch Report 2021

As part of the experience left by the COVID-19 pandemic, other types of events should now also be added, such as global crises, imminent and unexpected natural disasters, not in the role of insurmountable obstacles, but as plausible scenarios. that reiterate the need to be prepared for any eventuality that may arise in the near future.

\section{Collaborative work}

Academic work among teachers is complicated as mentioned by Buchanan et. al., (2007) who emphasize that the generation of a new culture for collaborative teams is still free from some challenges. Collaborative work, it is assumed, is planned and collegiate between professors in an institution, but in reality the professors turn out to be only colleagues in name, without effective work (Sessums, 2006; Hargreaves, 1994).

The Global Sentiment Survey on Training and Professional Development (Taylor, 2021) highlights that "the Training and Professional Development sector has reacted against the novelty" by using methodologies and tools that have proven to be effective in the past. In this same study, collaborative / social learning had a slight appreciation, which could mean that it has gone from a stage of content creation to a phase of "sharing connections and experiences".

\section{Team leadership}

According to Mbawmbaw et al. (2006) a leader can be seen with the qualities of trustworthy, inspiring-enthusiastic, formative, close and charismatic or with the traits of insecure, evasive, negligent, aggressive, abusive and manipulative.

According to Bass (1985), especially in the educational field, three types of leadership are distinguished: transformational leadership, transactional leadership and non-leadership (Barbuto and Brown, 2000). In the transformational there is influence, transformation, motivation, among other qualities. "Transactional leadership is a managerial style that promotes the fulfillment and achievement of goals through supervision, organization, and a system of rewards and punishments" (Wikipedia). And the nonleadership that can be only of appearance or name, of tyranny and imposition or only of doing nothing.

\section{Multidisciplinary synergy}

Below is an acrostic that includes the keywords that represent the ideal essence of the project. 


\begin{tabular}{|l|l|}
\hline $\mathbf{S}$ & $\begin{array}{l}\text { social, solid, smiling, satisfy, sustainable, sense, } \\
\text { sensitivity }\end{array}$ \\
$\mathbf{I}$ & innovative, interest, identify, comprehensive, \\
$\mathbf{N}$ & new, natural, nascent, business, \\
\hline $\mathbf{E}$ & energy, entrepreneurship, scale, start, \\
& empowerment, environment \\
$\mathbf{R}$ & reduction, challenge, robust, fast, reactivate \\
$\mathbf{G}$ & generator, great, generous, joy, governance, \\
& gratitude, \\
I & important, interesting, pristine, implicit, inherent \\
A & assertive, speed, nest, active, hug, action, current \\
\hline
\end{tabular}

Table 2 Acrostic of the word SYNERGY

Source: Table of own creatio

Synergy is understood as the relationship in which all the elements involved are strengthened and won due to the interaction. In the initiative presented here, it is intended that all the participating actors benefit from the interaction, mainly the students in the training process, who are the main objective, but it is also intended that the teachers grow, in experience and in training, with the ability to generate useful materials for other teachers who wish to replicate the practice;

Through these actions, it will be possible to establish indicators of effectiveness and efficiency of academic performance both inside and outside the institution in which they work.

Table 3 shows that the concept involves both emotional and non-emotional elements, elements that denote growth and evolution, that is, a continuous update, search and / or adaptation. From these premises it is established that the synergy will be executed in a singular way in each school year.

The synergy that has been exposed here entails an action research, mentioned by Bausela (2007), and defined by multiple authors, who establish that, according to its level, complexity and purpose, it is described in the form of a spiral model with successive cycles that includes diagnosis, planning, action, observation and reflection-evaluation.

\section{Methodology}

The present work aims to reflect on what has been experienced and obtained so far from the so-called synergy between two different careers of two university centers of the University of Guadalajara (UdeG), over two years (four school cycles), with the intention of improving the dynamics and current management.
By taking it to a methodology that works to achieve that it can be replicated in other scenarios between different careers. Everything presented here is only material of the qualitative experiential type and was the product of the results obtained from the experiences and perceptions of the participants. Validated analysis and comparison tools of the qualitative type were used to try to find the context of what happens, before and after the experience, between the ideal and the unsuitable scenarios.

\section{SWOT analysis of the experience}

Its important elements of success. Figure 1 presents the main strengths, opportunities, weaknesses and threats identified in the process.

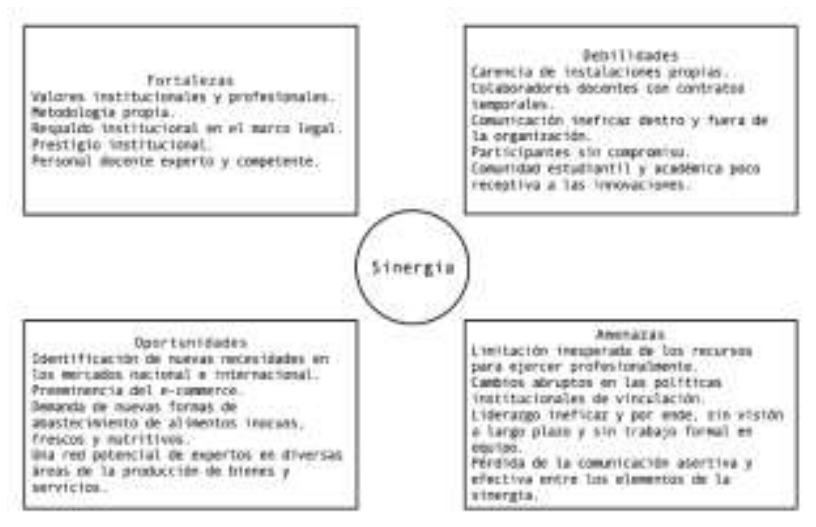

Figure 1 SWOT analysis

Through collegiate discussion, the SWOT analysis of the experience of synergy and Derived from the exercise of construction of the SWOT analysis for the experience of synergy in the 4 previous school cycles (2020-2021), categories could be obtained by the type of action and participation among which are mentioned: the institution, the teachers, the students, the context, the values, the tendencies and the multidisciplinary nature of the participants.

Within the internal conditions there are strengths and weaknesses, which describe what we have and what we have to face external conditions, opportunities and threats. 


\section{Results}

The creation of the SWOT analysis served as a trigger to identify that one of the academic and institutional solutions to address external factors - opportunities and threats - is the synergy between experts from multiple disciplinary areas, who have the initiative to consolidate the bonding between their students, taking advantage of the communication tools that virtuality provides. At the institutional level, it is a requirement that the administrative and academic instances coordinate to provide the resources and guarantee the functionality of the synergy within the corresponding legal framework.

At an interpersonal level, it is necessary for academics to commit themselves to achieve effective collaborative work, providing a little extra work to establish indicators that help better implementation, to apply them, analyze them and redesign the strategies each beginning of the school year. The foods on which the students of the different careers intervene are novel proposals and their commercialization is a priority in society and in the world. Likewise, the team can be strengthened by linking with strategic allies that support the management and analysis of the results that are obtained, which must be offered as a result of analysis by the institution.

On the other hand, communication with society about the achievements of synergy should be encouraged. In this way, by inviting teachers and researchers to work in collaborative networks, disqualification and mistrust that is presented as one of the weaknesses of the project is avoided, both by the participating students and by external teachers who have not yet understand the importance of their own bonding work.

\section{Notes on the role of the leader in synergy}

Given the nature of the project, the teachers who were invited to participate took the convening entity as the "leader" of the proposal. It is evident that the role of the leader is not well established and they took him as the guide and responsible for all phases of the process. In operation, the collaborators have expected the leader to carry out the work of data collection, planning, reporting and also expect him to be the convening entity.
As mentioned in the reflection on the transactional leader, the leader is a facilitator, collaborator, axis, motivator and mediator. It is the entity that challenges the process, inspires a shared vision, invites others to act, serves as a role model, and provides encouragement. Similarly, it establishes the commitments of all the elements called, suggests strategies to seek support and defines activities and actions. This role of transactional leader cannot be carried out if teachers do not change their attitudes and do not do an exercise of self-reflection on what they have been doing, since synergy requires that the needs of the participants be taken into account and growth is sought, everyone's satisfaction and enjoyment.

\section{Comparison of the traditional teaching- learning scenario and the scenario involving synergy between the participating careers}

What was intended to be done with Synergy (with synergy) derived from the diagnosisperception (without synergy) from which the teachers involved in this start are described below.

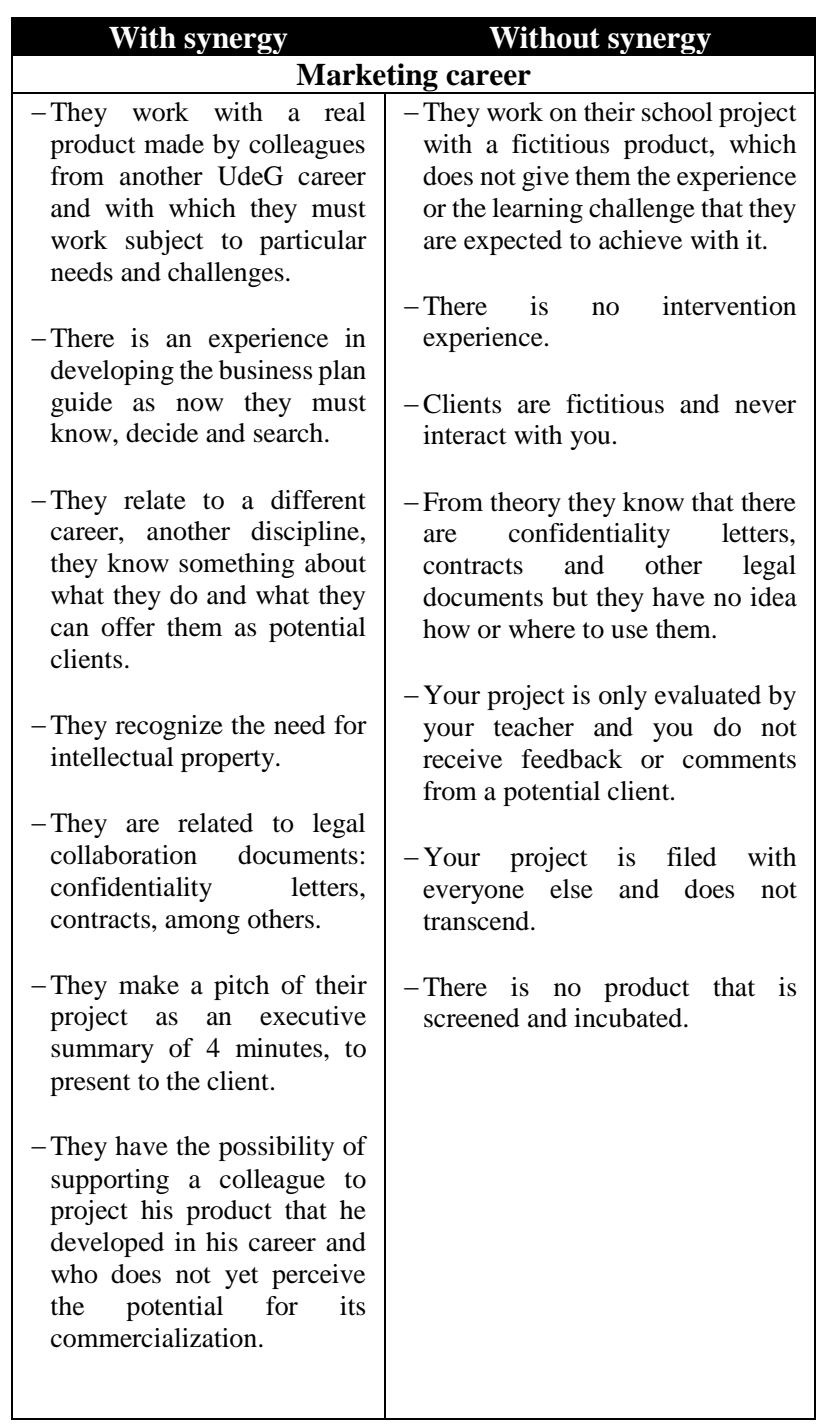




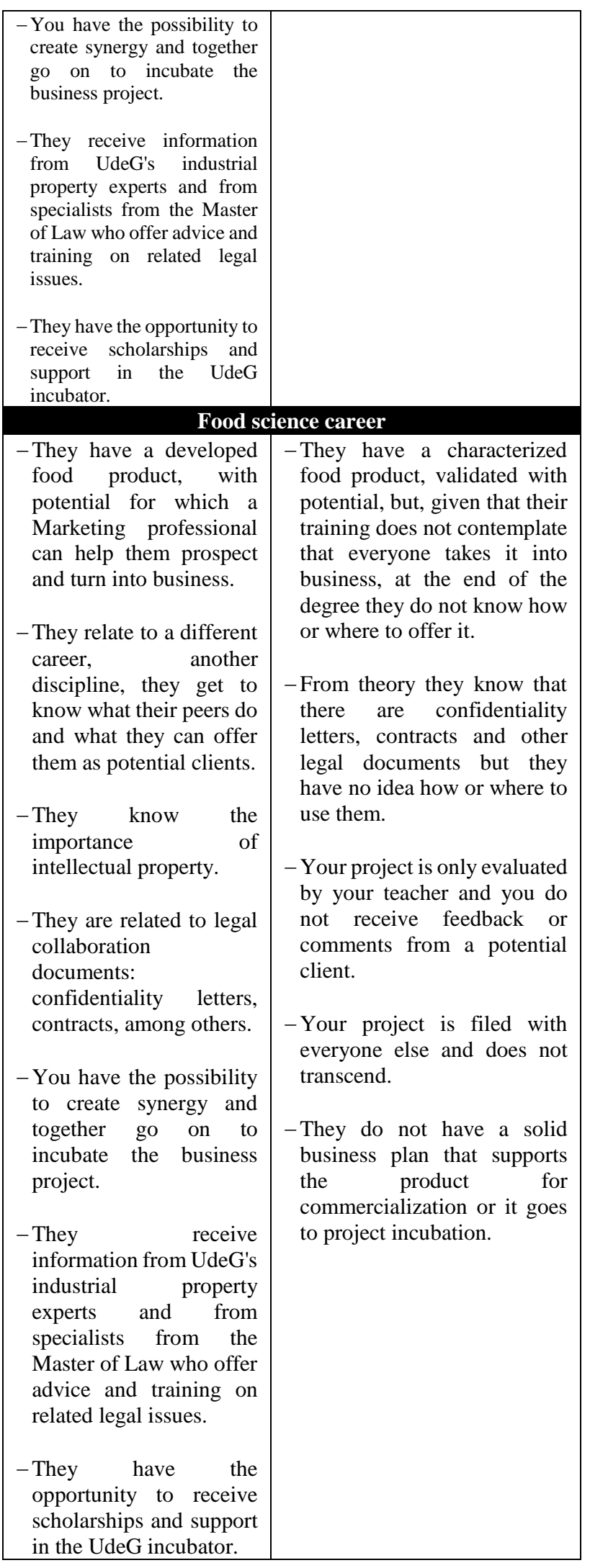

Table 4 Comparative table of the advantages of having synergy for the two races

From this comparison, of the segment "with synergy", we can find the multiple benefits that students obtain in their learning unit by being active participants in this dynamic of bonding.

\section{Conclusions}

Institutional support is required for the recognition of teaching work in linking, the designation of computer and digital resources for the development of all synergy activities, collaboration with the teaching, administrative and student human capital for the management and analysis of data and results and the support of official communication networks in the dissemination of the works and their results.

It is essential that support is provided to subject teachers so that they can participate without so many work limitations. Finally, support for students should be encouraged to participate in this preparation goal different from the traditional disciplinary one; In this way, the competence-based educational model is made effective by encouraging students to learn by DOING, so that upon graduation they have the knowledge and disciplinary experience and the soft skills that are so demanded by employers.

\section{References}

Aguilar, J. (2021). Actitudes ambientales en los estudiantes de la preparatoria San José del Valle. (tesis de maestría, Universidad de Guadalajara).

Bass, B. M. \& Avolio, B. J. (1994). Improving Organizational Effec-tiveness. Through Transformational leadership. California, USA: Sage Publications.

Barbuto, J. E. \& Brown, L.L. (2000). Full range leadership. NebGuide, D-27, University of Nebraska-Lincoln, USA: Cooperative Extension, Institute of Agriculture and Natural resources.

Bausela, E. (2007). La docencia a través de la Investigación Acción. En Revista Iberoamericana de Educación. Consultado el 10 de diciembre de 2021 en: http://www.rieoei.org/deloslectores/682Bausela .PDF

Buchanan, Merilyn; Bleicher, Robert E.;Behshid, Sima; Evans, Charmon; Ngarupe, Linda (2007). Ensuring Teacher Retention in a PDS. Online Submission. En Eric Database. Identificador No. ED 497416. Consultado el 15 de diciembre de 2021 en: http://www.eric.ed.gob/search 
Echavarría, L. y De los Reyes, C. (2017). El modelo de educación basado en competencias: genealogía, análisis y propuestas. Memorias del COMIE. Consultado el 17 de diciembre de 2021 en: https://bit.ly/2YzpITS

Hargreaves, A. (1994). Changing teachers, changing times: teachers' work and culture in the postmodern age. New York: Teachers College Press.

Martín Sabina, E., González Maura, V., \& González Pérez, M. (2017). Experiencias en el apoyo a la formación de profesores de la educación superior. Tarbiya, Revista De Investigación E Innovación Educativa, (30). Consultado el 19 de diciembre de 2021 en: https://revistas.uam.es/tarbiya/article/view/ 7391

Mbawmbaw Omiaziki Jeff , María Elena Rivera Heredia, Nadina Valentín Kajatt,Raymundo Téllez Rodríguez, Rafael Nieto Göller. Dimensiones del liderazgo docente.Consultado el 10 de diciembre de 2021 en: file:///Users/aracelihernandeztinoco/Downloads /Dialnet-DimensionesDelLiderazgoDocente2986653-1.pdf

Sessums, C. (2006). Collaboration and Collegiality in Teacher Professional Consultado el 15 de diciembre de 2021 en: http://eduspaces.net/csessums/weblog/11364.ht $\mathrm{ml}$

Taylor, D. (2021). Encuesta de sentimiento global sobre formación de desarrollo profesional. Consultado el 25 de noviembre de 2021 en:

https://www.netexlearning.com/encuestaformacion-desarrollo-2021-donald-taylorespanol/

World Trends Watch Report 2021, Consultado el 19 de diciembre de 2021 en: https://mdcmagazine.com/articulos/industry/MI CE/5-megatendencias-para-2021 